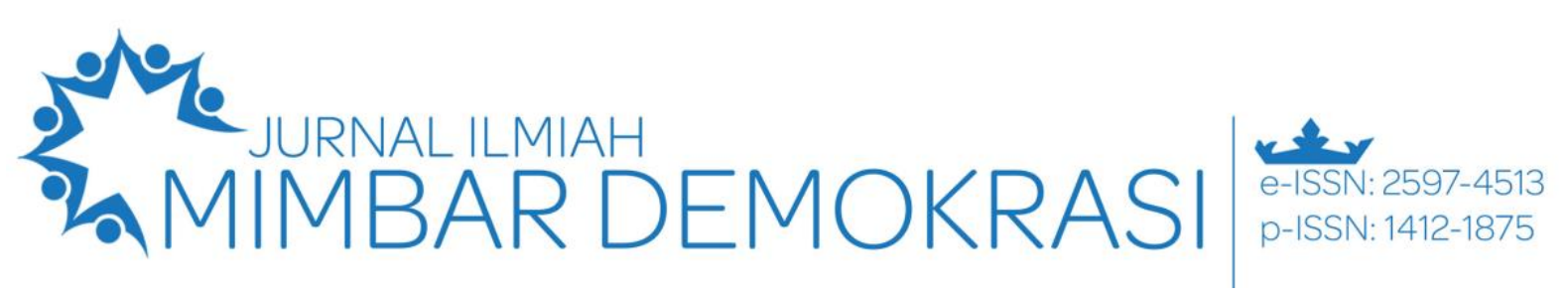

Vol. 19 No. 2 Tahun $2020 \mid$ Hal. $12-27$

\title{
Pertalian Agama pada Pilkada DKI Jakarta Tahun 2017
}

\author{
Muhamad Ridwan Effendi a, 1*, Iqbal Syafrudin b, 2* \\ a Universitas Negeri Jakarta, Indonesia \\ 1 muhamadridwan@unj.ac.id*; 2syarudin@unj.ac.id \\ *Dosen Fakultas Ilmu Sosial Universitas Negeri Jakarta
}

\begin{tabular}{l}
\hline Informasi artikel \\
\hline Diterima: \\
03-03-2020 \\
Disetujui: \\
03-04-2020 \\
Kata kunci: \\
Agama \\
Politik \\
Identitas \\
Aksi \\
Konflik
\end{tabular}

\begin{abstract}
ABSTRAK
Artikel ini bertujuan menguraikan tentang hubungan antara agama dan politik yang terjadi di DKI Jakarta dalam kerangka Pemilihan Umum Kepala Daerah (Pilkada) pada tahun 2017 lalu sebagai salah satu saluran demokrasi di Indonesia. Melalui metode dan pendekatan kualitatif deskriptif, peneliti lebih memfokuskan kajiannya pada serangkaian peristiwa demonstrasi besar-besaran yang terjadi di Jakarta dengan dinamai “Aksi Bela Islam” oleh kelompok penggeraknya yaitu GNPF-MUI (Gerakan Nasional Pengawal Fatwa Majelis Ulama Indonesia) yang berpengaruh terhadap konstelasi politik saat itu. Artikel ini menunjukkan bahwa Aksi Bela Islam telah menunjukkan keterlibatannya dalam arena politik yang bergejolak, dan proses tersebut telah membentuk watak situasi politik yang terjadi dalam Pilkada DKI Jakarta. Selain itu, kajian ini pun menunjukkan bahwa proses demokrasi yang tengah berjalan telah memungkinkan munculnya identitas agama dalam Pilkada DKI Jakarta.
\end{abstract}

Keywords:
Religion
Politic
Identity
Action
Conflict

\begin{abstract}
Religious Relation in DKI Jakarta Election in 2017. This article aims to elaborate on the relationship between religion and politics that occurred in DKI Jakarta within the framework of the 2017 Regional Head Election (Pilkada) as one of the channels of democracy in Indonesia. Through descriptive qualitative methods and approaches, researchers focus their studies more on a series of large-scale demonstration events that took place in Jakarta named "Action of Defending Islam" by its activist group, the GNPF-MUI (National Movement for Guarding Fatwa of the Indonesian Ulema Council) which affects the political constellation at that time. This article shows that the Islamic Defending Action has demonstrated its involvement in the turbulent political arena, and the process has shaped the political situation in the Jakarta Election. Also, this study also shows that the ongoing democratic process has enabled the emergence of religious identity in the DKI Jakarta Election.
\end{abstract}

Copyright (C) 2020 (Muhamad Ridwan Effendi, Iqbal Syafrudin). All Rights Reserved

How to Cite: Effendi, M.R., \& Syafrudin, I. (2020). Pertalian Agama pada Pilkada DKI Jakarta Tahun 2017. Jurnal Ilmiah Mimbar Demokrasi, 19(2), 12-27. DO: 10.21009/jimd.v19i02.14528

This work is licensed under a Creative Commons Attribution-Share Alike 4.0 International License. Allows readers to read, download, copy, distribute, print, search, or link to the full texts of its articles and allow readers to use them for any other lanful purpose. The journal hold the copyright.

\section{Pendahuluan}

Pada tahun 2017 lalu, Indonesia tengah disibukan dengan hajat demokrasi 5 (lima) tahunan, yakni pemilihan umum kepala daerah (Pilkada) yang berlangsung di beberapa daerah di Indonesia, salah satu yang cukup menarik perhatian publik adalah Pilkada yang berlangsung di DKI Jakarta. Hal yang menarik dalam Pilkada DKI Jakarta, bukanlah pada mekanisme penyelenggaraannya, melainkan pada manuvermanuver politik yang dilakukan para aktor politik dan kontestan peserta pilkada sebagai sebuah media untuk membangun opini publik serta demonstrasi besar-besaran yang terjadi di tengah perhelatan Pilkada DKI Jakarta yang cukup fenomenal dan mendapat perhatian masyarakat, tak terkecuali masyarakat Internasional. 


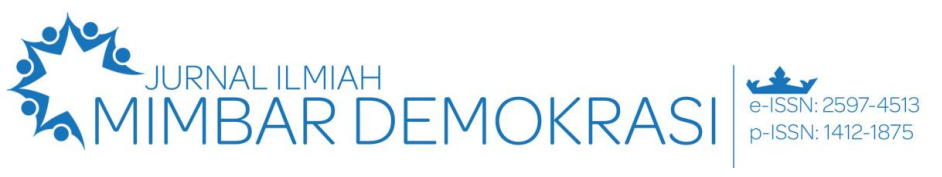

\section{Vol. 19 No. 2 Tahun 2020 | Hal. 12 - 27}

Demonstrasi besar-besaran yang sudah berlangsung 4 (empat) kali1 itu merupakan aksi massa terbesar pasca tumbangnya Orde Baru, dan aksi yang dimotori oleh penggeraknya dengan menamakan diri Gerakan Nasional Pengawal Fatwa MUI (GNPF-MUI). Aksi demonstrasi ini menuntut agar aparat hukum segera memproses kasus pidana penistaan agama,2 yang menurut fatwa MUI bertanggal 11 Oktober 2016, telah dilakukan oleh Basuki Tjahaja Purnama alias Ahok, seorang Gubernur DKI Jakarta yang juga sebagai calon petahana pada Pilkada DKI Jakarta, dan bergeser lebih jauh berisi tuntutan pemenjaraan atas ditetapkannya Ahok sebagai tersangka dalam kasus tersebut. Ratusan ribu orang turun ke jalan. Tak hanya ulama dan umat kebanyakan, tapi ada juga turut hadir dari kalangan artis dan politisi nasional. Puluhan ribu aparat polisi pun dikerahkan untuk mengamankan jalnannya demontrasi tersebut.

Peristiwa yang oleh penggeraknya dinamai "Aksi Bela Islam" tersebut menarik perhatian banyak pihak. Bukan hanya karena begitu besarnya massa yang turun ke jalanan ibukota, tapi juga, bagi sebagian orang, karena persoalan lebih dalam menyangkut agama-politik di balik hiruk-pikuk massa demonstrasinya. Di tingkat masyarakat awam, perbincangan terkait hal ini begitu merasuk dan hampir selalu muncul dalam obrolan tiap hari, entah dalam pertemuan langsung, apalagi dalam WAG (Whats App Group) maupun grup chat lainnya. Tak sekadar menjadi pembicaraan massa awam, di tingkat elite, isu ini juga mendorong manuver-manuver para aktor politik, baik yang bertujuan memolitisir isu ini (dan menungganginya untuk kepentingan politik pribadi dan kelompoknya) maupun yang hendak meredam eksploitasi kasus penistaan agama maupun "Aksi Bela Islam".

Selain mengagetkan banyak pihak dengan massa yang demikian besar, "Aksi Bela Islam" yang belakangan populer dengan sebutan aksi 411, 212, 313 ini, tak pelak menyeret hampir sebagian besar umat Islam pada nada-nada retorika yang muncul di sekitar aksi demonstrasi sudah begitu sangat mengerikan. Tuduhan penistaan agama yang ditujukan kepada Gubernur Basuki Thajaja Purnama alias Ahok

\footnotetext{
1 Gelombang Aksi Bela Islam (selanjutnya diebut ABI) Pertama, ABI 1 pada tanggal 15 Oktober 2016; Kedua, ABI 2 dikenal Aksi 412 karena dilakukan pada tanggal 4 Desember 2016; Ketiga, ABI 3 yang dikenal Aksi 212 karena dilakukan pada tanggal 2 Desember 2016; dan Keempat, ABI 4 yang dikenal Aksi 313 karena dilakukan pada tanggal 31 Maret 2017.
}

yang juga sebagai calon gubernur petahana Gubernur yang juga merupakan keturunan Tionghoa beragama Kristen telah bertumpuk dengan pidato-pidato penuh kebencian dengan nada rasis. Bahkan berbagai spanduk berisi materi kekerasan etnis telah terpasang sepanjang masa kampanye Pilkada DKI Jakarta, seolah mengembalikan ingatan perih tentang kekerasan yang menimpa keturunan Tionghoa pada 1998 silam. Bahkan sejak semula perdebatan ini bagi sebagian pihak dinilai tidak produktif dan tidak menyentuh pada pokok persoalan yang dihadapi umat Islam Indonesia saat ini terkait keadilan sosial dan keadilan ekonomi.

Pada tataran akan rumput, perdebatan telah berubah menjadi saling caci antar umat Islam terlebih pendukung Habib Rizieq dan Ahok. Para pendukung "Aksi Bela Islam" menuding mereka yang tidak setuju atau tidak mendukung aksi sebagai perwujudan kurang Islam. Sementara bagi para penolak "Aksi Bela Islam" menganggap aksi massa yang memobilisasi ratusan ribu orang untuk turun ke jalan, alih-alih membela Islam, justru merendahkan Islam dan tak lebih sebagai buang-buang energi umat Islam untuk hal yang tidak substansial dan remeh temeh. Bahkan, lebih jauh, sebagian besar para pengkritik "Aksi Bela Islam" menganggap aksi massa tersebut sebagai bukan metode perjuangan Islam.

Kedua cara pandang inilah yang menurut hemat saya perlu untuk ditanggapi secara serius, sekaligus sebagai ikhtiar mendudukkan persoalan "Aksi Bela Islam" tidak sekedar persoalan teologis, melainkan membacanya sebagai dinamika pertarungan maupun konvergensi kepentingan antar elite politik dalam lanskap politik elektoral DKI Jakarta. Pernyataan Ahok dengan mengutip Surat al-Maidah 51 paa Oktober 2016 lalu telah dieksploitasi sedemikian dalamnya, untuk memunculkan identitas politik masyarakat urban yang menjadikan Jakarta sebagai etalase kemajuan Indonesia.

Meninjau hasil kajian pustaka yang disadur pada penelitian sebelumnya, terdapat beberapa hasil penelitian yang dianggap sejenis terkait dengan pembahasan dalam penelitian ini, di antaranya: pertama, artikel jurnal yang ditulis oleh Hasbullah, Agama dan Etnisitas di Pentas Politik

\footnotetext{
2 Ahok dinilai telah melakukan pelecehan terhadap al-Quran sebagai kitab suci umat Islam, hal ini berawal dari petikan pidatonya saat berkunjung di Pulau Seribu yang menyulut kemarahan ulama dan umat Islam terkait Q.S. al-Maidah ayat 51.
} 
Lokal (Tinjauan Terbadap Penggunaaan Simbol Agama dan Etnis dalam Pilkada) yang dalam simpulannya diungkapkan bahwa penggunaaan simbol-simbol keagamaan dalam praktik politik praktis seperti Pilkada merupakan media untuk menggiring opini dengan menjadikan simbol agama sebagai isu potensial (Hasbullah, 2011). Kedua, jurnal yang ditulis Nur Latifah, Agama, Konflik Sosial, dan Kekerasan Politik yang dalam simpulannya lebih menekankan bahwa konflik yang terjadi di Maluku merpakan refleksi pertikaian elite politik sebagai akibat dari adanya ketidakadilan politik yang kemudian menjadi terpolarisasi ke ranah pemeluk agama. Ketiga, Tesis karya Muhamad Ridwan Effendi, Isu-isu Agama dalam Pilkada Kabupaten Purwakarta, dalam tesisnya dijelaskan bahwa isu-isu agama yang muncul dalam Pilkada Purwakarta terjadi sebagai bentuk perlawanan rivaitas politik dan dampak adanya kebijakan-kebijakan pembangunan daerah yang diangap tidak sejalan dengan tradisi dan budaya masyarakat Purwakarta (Effendi, 2013).

Meskipun dalam beberapa aspek penelitian di atas terdapat adanya kemiripan, akan tetapi tidak sepenuhnya sama baik dalam judul, latar belakang masalah, tujuan, metodologi, teori dan kesimpulan yang digunakan. Sehingga dalam penelitian ini, mulai dari latar belakang, analisis teori, fokus dan lokusnya pun terdapat perbedaan yang kontras

Berdasarkan studi pendahuluan di atas, telah menarik minat penulis untuk memahaminya secara lebih sistematis. Dalam penelitian ini, penulis hendak menguraikan aksi yang terkesan bernuansa agama tersebut ada hubungannya hubungannya dengan situasi politik yang tengah terjadi di DKI Jakarta. Sehingga ajuan pertanyaan penelitian ini, adalah apa yang melatarbelakangi munculnya Aksi Bela Islam GNPF-MUI di DKI Jakarta? Dan bagaimana implikasi Aksi Bela Islam GNPF-MUI terhadap kondisi politik DKI Jakarta saat itu?.

\section{Metode}

Adapun dalam penelitian ini penulis menggunakan metode kualitatif deskriptif dengan teknik pengumpulan data melalui wawancara kepada peserta Aksi Bela Islam dan kajian dokumentasi sumber-sumber lainnya seperti buku, majalah, koran, dan informasi lainnya seperti facebok, Instagram, Whats App yang kemudian di analisis dengan teknik triangulasi data dan teori-teori yang relavan dalam penelitian ini.

\section{Hasil dan pembahasan}

\section{A. Agama dan Politik}

Kajian terkait hubungan agama dan politik seakan tidak akan pernah berakhir. Karena kedua-duanya merupakan bagian dari instrument yang penting dalam kehidupan manusia. Secara naluriah, tentunya manusia pasti memiliki agama dan agama itu mempengaruhi kehidupan individu dan social manusianya. Istilah zoon politicon (political animal) atau binatang yang berpolitik merupakan istilah yang diungkapkan oleh Aristoteles dengan maksud untuk menggambarkan bahwa pada hakikatnya manusia sebagai makhluk sosial tidak akan pernah bisa hidup menyendiri dan tidak membutuhkan manusia lainnya terlebih dalam urusannya untuk memepreloh sesuatu yang diinginkan tentunya ia akan memerlukan instrumen lain sebagai medianya, termasuk agama dan politik sekalipun.

Meskipun hubungan agama dan politik itu sangat erat dan saling mempengaruhi, perbincangan terkait keduanya seringkali menimbulkan kontroversi. Dalam hal ini, paling tidak ada dua pandangan besar yang tidak saja berbeda, tetapi juga bertolak belakang. pertama adalah pandangan bahwa agama tidak dapat dipisahkan dari masalah-masalah keduniaan, apakah itu sosial-budaya, ekonomi, maupun politik. Karenanya, antara agama dan persoalan keduniaan tersebut ada kaitan formal. Tentunya bagi orang beragama, argumen ini tidak pantas kiranya memisahkan persoalan-persoalan dunia dari agama. Dan kedua adalah pandangan bahwa bukan saja agama itu berbeda dengan persoalan keduniaan, tetapi antara keduanya tidak ada hubungan sama sekali, dan karenanya harus dipisahkan. Perdebatan seperti itu biasanya diikuti dengan munculnya penilaian-penilaian yang sifatnya judgmental kepada masing-masing pendukung pandangan di atas. Mereka yang mendukung pandangan yang pertama sering diasosiasikan sebagai pemeluk agama yang skriptualis atau fundamentalis. Sedangkan mereka yang mendukung pendapat yang kedua biasanya dihubungkan dengan sikap hidup sekuler (Effendy, 2000).

Namun tidak semua pernyataan bahwa agama dan politik memiliki keterkaitan seperti yang dibenarkan oleh sebagian pihak di atas tadi, karena bagi beberapa orang di antaranya ada pendapat yang mengemukakan bahwa tidak ada keterlibatan agama dalam politik praktis, pendapat ini menganggap bahwa politik memiliki wilayah yang berbeda, bahkan berseberangan dengan agama (Kahmad, 2011). Karenanya 


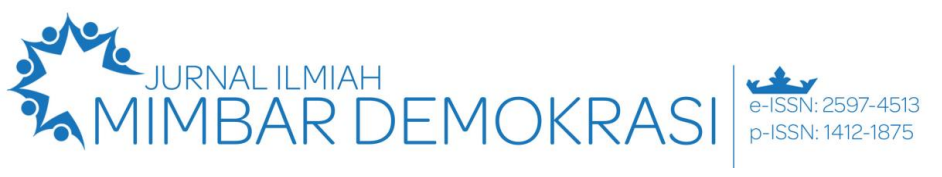

Vol. 19 No. 2 Tahun 2020 | Hal. 12 - 27

agama merupakan persoalan pribadi (Private), sedangkan politik adalah hal lain di luar urusan agama dan bersifat publik(umum).

Seperti apa yang telah diungkap di atas, peran an agama dalam kehidupan ini memberikan dampak yang nyata bagi perubahan sosial masyarakat. Agama dianggap sebagai fenomena sosial yang selalu menarik bagi penyelidikan keilmuan. Maklum saja, agama bukan hanya merupakan kebutuhan psikologis manusia. Agama juga bukan gejala keilahian yang dapat dipertanggungjawabkan secara teologis belaka. Agama juga suatu lembaga sosial yang mempunyai fungsi sosial dan kiranya juga mempunyai asal-usul sosial pula (Sindhunata, 2006). Agama bukan hanya gejala adikodrati tetapi juga gejala kodrati. Menurut Sindhunata agama memang suatu institution divina, yang menyimpan keilahian, kesucian, misteri, bahkan irasionalita, yang tak dapat begitu saja diterangkan secara ilmiah dan rasional. Namun sebagai institution bumana, agama dapat juga dikupas dan diterangkan secara ilmiah dan rasional (Sindhunata, 2006).

Terlepas dari perkara keterlibatan agama dalam pengaruh lingkungan tersebut, artikulasi agama pun dimaknai memiliki peran aktif dalam hal politik. Berbicara tentang politik, pengertiannya selalu diasosiasikan dengan masalah pemerintahan, kekuasaan, konflik, partai politik atau upaya-upaya yang ditempuh perseorangan maupun kelompok untuk memperjuangkan kepentingan warga Negara. Karena itulah, istilah politik sesungguhnya merangkum pengertian yang luas.

Sebagaimana inventarisasi makna politik yang diungkapkan Ramlan Surbakti (Subekti, 1999). Pertama, politik adalah usaha-usaha yang ditempuh warga Negara untuk membicarakan dan mewujudkan kebaikan bersama; Kedua, politik sebagai segala sesuatu yang berkaitan dengan penyelenggaraan Negara dan pemerintahan; Ketiga, politik sebagai segala kegiatan yang diarahkan untuk mencari dan memeprtahankan kekuasaan dalam masyarakat; Keempat, politik sebagai kegiatan yang berkaitan dengan perumusan dan pelaksanaankebijakan umum; dan Kelima, politik sebagai konflik dalam rangka mencari dan atau mempertahankan sumber-sumber yang dianggap penting.

Diskursus agama dan politik, khususnya menyangkut pengelolaan kekuasaan sebenarnya telah berkembang sejak abad tengah. Smith membagi pemikiran agama dan politk tersebut secara dikotomis ke dalam tipologi religio-political power organik di satu pihak dan sekuler di lain pihak. Para eksponen perspektif organik, mengklaim perlunya penyatuan agama dan kekuasaan karena jangkauan agama meliputi seluruh aspek kehidupan. Sementara itu eksponen perspektif sekuler cenderung mengklaim perlunya pemisahan antara agama dan kekuasaan, antara lain dimaksudkan untuk menjaga "keparipurnaan" agama itu sendiri (Smith, 1985).

Perkembangan pemikiran interelasi antara agama dan politik juga masuk dalam diskursus intelektual muslim kontemporer. Dalam hal ini muncul eksponen intelektual muslim yang memilih menjadi penganut perspektif organik, dan ada pula yang memilih perspektif sekuler. Oleh karena itu, tidak ada klaim yang bersifat tunggal atau hanya ada satu perspektif dalam Islam. Pemisahan peran agama dan Negara, menurut Swidler misalnya hanya representasi dari pemikiran Kristen. Sementara dalam Islam berlaku penyatuan agama dan Negara. Adapun dalam kalangan Yahudi cenderung ambigu, meskipun pandnagan Swidler ini dapat diperdebatkan, sebab seperti dikatakan Davis, Yahudi lebih menerpakan penyatuan agama dan Negara atau politik, sebagaimana mereka menggunakan agama untuk menjustifikasi klaim atas tanah Tepi Barat jalur Gaza sebagai hadiah Tuhan (Maliki, 2010).

\section{B. Konflik Sosial dan Politik Identitas}

Pertautan agama dan politik pun menjadi kontroversi bagi sebagian kaum agamawan, di satu pihak menganjurkan keterlibatan agama dalam politik sebagai wujud keyakinan bahwa agama merupakan ajaran universal yang tidak menutup kemungkinan bahwa dengan berpolitik merupakan bagian dari salah satu ibadah sosial yang harus dijalankan (Muhubbin, 2012), di lain pihak adanya larangan keterlibatan agama dalam politik, dikarenakan politik adalah wilayah yang berbeda, bahkan berseberangan dengan agama sehingga agama harus steril dari warna-warni politik.

Terlepas adanya kontroversi yang mempertautkan antara agama dan politik dewasa ini, nampakknya dapat dilihat dari adanya pemanfaatan agama sebagai sebuah isu dalam politik yang menimbulkan dampak serius dan melahirkan sederet konflik sosial di masyarakat yang berujung pada tindakan fundamentalisme. Sebagai sebuah contoh fenomena Pilkada yang terjadi dibeberapa daerah beberapa waktu yang lalu, seperti Pilkada Pilgub Jakarta yang syarat 
akan pemanfaatan agama sebagai media propaganda dalam mempengaruhi massa yang diwujudkan dengan keterlibatan berbagai simbol, aktor dan statement yang berhubungan dengan agama.

Aksi pemanfaatan agama sebagai media politik dinilai sebagai senjata mematikan bagi mayoritas masyarakat beragama, pasalnya secara umum masyarakat Indonesia merupakan masyarakat beragama, terlebih mayoritas penduduknya beragama Islam. Corak keagamaan yang dipraktikan dalam aktivitas sosial, ekonomi, budaya dan politik didasarkan pada ortodoksi Ablussunnah wal Jama'ah. Ortodoksi tradisi nilai keagamaan tersebut dijadikan sebagai sikap hidup bagi masyarakat yang dibesarkan dalam lingkungan masyarakat yang beragama Islam. 3

Kasus Ahok yang kemudian merembet ke dalam persoalan Aksi Bela Islam itu merupakan sebuah gambaran keberhasilan politik identitas dalam memenangi sebuah kompetisi politik. Keberhasilan politik identitas yang digaungkan beberpa elit politik yang meskipun di sebagian pihak menyebutkan bahwa Aksi Bela Islam dianggap murni sebagai bentuk protes dan penegakakan hukum atas kasus Ahok dan bukan sebagai aksi yang dilandasi kepentingan politik. Meskipun demikian, potret yang terjadi beberapa simbol dalam politik identitas terkait SARA pun muncul.

Langkah politik identitas yang terjadi pada aksi dan kasus tersbeut dirasa dimanfaatkan oleh sebagian pihak elite politik guna mendapatkan populraitas dan elektablitas pihak-pihak yang degan sengaja memanfaatkan momentum tersebut.

Perlu diketahui bahwa yang dimaksud politik identitas menurut Widayanti (2009) adalah nama lain dari biopolitik dan politik perbedaan. Biopolitik mendasarkan diri pada perbedaanperbedaan yang timbul dari perbedaan tubuh. Identitas menurut Jeffrey Week adalah berkaitan dengan belonging tentang persamaan dengan sejumlah orang dan apa yang membedakan seseorang dengan yang lain. Pendapat Jeffrey Week tersebut menekankan pentingnya identitas bagi tiap individu maupun bagi suatu kelompok atau komunitas. Agnes Haller mengambil definisi politik identitas sebagai konsep dan gerakan politik yang fokus perhatiannya adalah perbedaan (difference) sebagai suatu kategori politik yang utama.

\footnotetext{
3 Meskipun informasi ini mengambarkan sebagian corak keagamaan yang dianut masyarakat Jakarta, setidaknya dapat digunakan untuk memahami realitas politik
}

Kendatipun demikian, realitas sepanjang kasus itu terjadi politik identitas memangtengah terjadi dan bahkan masih sangat diminati oleh elit politik untuk memenangkan kompetisi politik. Identitas pembeda mereka salah satunya adalah agama.

Pemanfaatan identitas sebagai saluran politik tentunya akan memberikan dampak terhadap stabilitas sosial, dan ketiak tidak terkontrol maka akan melahirkan konflik sosial di masyaraat secara luas. Konflik sosial itu muncul sebagai langkah fundamental dalam menyerukan hak dan keinginan politiknya secara terbuka, meskipun hasil akhirnya akan berhasil atau bahkan chaos.

$\begin{array}{ccc}\text { Menurut } & \text { Horace } & \text { M. Kallen, } \\ \text { ditandai } & \text { oleh } & \text { tiga }\end{array}$ kecenderungan umum (Karyono, 2003). Pertama, fundamentalisme merupakan respons terhadap kondisi yang sedang berlangsung. Respons tersebut muncul dalam bentuk evaluasi, penolakan, atau bahkan perlawanan. Masalahmasalah yang ditolak dapat berupa asumsi, ide, lembaga, atau nilai-nilai yang dapat bertanggung jawab terhadap keberlangsungan keadaan yang ditolak.

Kedua, fundamentalisme tidak berhenti pada upaya penolakan, melainkan terus berupaya mengganti tatanan lain. Ciri ini menunjukkan bahwa di dalam fundamentalisme terkandung suatu program atau pandangan dunia (world view) tersendiri. Kaum fundamentalis berupaya kuat untuk menjadikan tatanan tersebut sebagai ganti dari tatanan yang sudah ada. Dan ketiga, kaum fundamentalis memiliki keyakinan yang kuat akan kebenaran program atau ideologi yang mereka bawa. Dalam gerakan sosial, kaum fundamentalis memperjuangkan keyakinan yang mereka anggap benar dengan sikap emosional yang menjurus pada kekerasan.

Perubahan sosial, memang sering ditempuh melalui gerakan fundamental disertai kekerasan yang ternyata kemudian melahirkan sejarah perlawanan dalam bentuk revolusi sosial fundamental. Revolusi sosial itu didasarkan pada ideologi sekuler (Maliki, 2010). Di samping adanya perlawanan atau revolusi sosial yang berangkat dari ideologi sekuler, maka di sisi lain muncul perlawanan atau revolusi sosial yang digerakkan oleh sebuah keyakinan keagamaan. Agama dalam pengertian tradisional memang menaruh perhatian kepada sistem keyakinan, nilai

masyarakat Jakarta. Hasil wawancara dengan Pengurus Forum Kewaspadaan Dini Masyarakat Jakarta (FKDM) Jakarta, Dr. H. Anang Abdul Razak, M.Pd. 


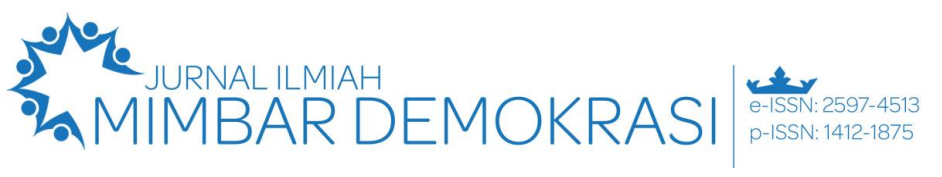

\section{Vol. 19 No. 2 Tahun 2020 | Hal. 12 - 27}

dan motivasi kehidupan yang berbeda dengan sistem nilai yang dibangun masyarakat sekuler. Sistem nilai itu diinternalisasi oleh pemeluknya dan sebagian toleran tetapi sebagian yang lain kemudian mendorong lahirnya cara-cara peneyelesaian fundamental bahkan dengan kekerasan atas nama agama. Mereka yang mencari solusi dari krisis sosial dengan cara-cara fundamental dan mengatasnamakan "agenda suci" itulah yang sering dikenal sebagai gerakan fundamentalisme agama (Twiss, 1997).4

Ketika agama secara empiris dihubungkan dengan persoalan sosial-kemasyarakatan hendaknya disertai dengan kesediaan untuk meletakkannya dalam perspektif yang menekankan pada dimensi isi, meskipun dalam perjalanannya akan sering ditemukan keteganganketegangan antara wilayah agama dan sosial kemasyarakatan termasuk politik. Bahkan dalam kaitannya dengan hal ini, Mohamad Natsir pernah memberi cap lâ dîniyyah (sekuler) terhadap ide-ide sosial-politik yang tidak bersumber dari ajaran agama (Twiss, 1997).

Ketika agama dekat dengan gerakan-gerakan fundamentalisme, peran dan fungsi agama menjadi kerdil bahkan tidak sejalan dengan citacita awal agama itu sendiri untuk memberikan kedamaian dan ketenangan batin bagi setiap pemeluknya. Seolah-olah agama menjadi senjata bagi mereka untuk melakukan gerakan-gerakan dakwah yang sifatnya memaksakan ummat lain untuk ikut dan taat pada agama yang dianutnya. Hal semacam ini didasari dengan dalih semangat "jihad" atau tegaknya "kerajaan Tuhan" di muka bumi. Hal ini merupakan dampak dari adanya sikap eksklusif (Grose, 1998) dalam beragama.

Beberapa pendapat mengatakan bahwa tantangan yang dihadapi dewasa ini sebenarnya bukan dalam bidang ekonomi, politik, sosial dan budaya, akan tetapi Ghazwah al-Fiqri atau tantangan pemikiranlah yang sedang kita hadapi saat ini. Sebab persoalan yang ditimbulkan oleh bidang-bidang ekonomi, politik, sosial, dan budaya ternyata bersumber dari pemikiran. Di antara tantangan pemikiran yang paling serius saat ini adalah dibidang pemikiran keagamaan. Tantangan yang sudah lama kita sadari adalah tantangan internal yang berupa kejumudan, fanatisme, taklid buta, dan sebagainya. Begitu pun dengan tantangan ekternal yang kerap

\footnotetext{
4 Kata fundamentalisme pertama kali digunakan pada tahun 1920 dipakai untuk menyebut suatu pemeluk agama yang taat, yang menunjukkan pada suatu gerakan di dalam kekristenan yang ingin menjaga dan memurnikan kesempurnaan Alkitab, sembari tidak sabar menunggu
}

memunculkan perselisihan paham dan bentrokan antar agama, yang jelas tantangan tersebut digawangi dengan munculnya sikap dan cara berpikir fundamentalisme-literalis bagi oknum pemeluk agama.

Munculnya ragam gerakan fundamentalisme dewasa ini yang dimotivasi keyakinan agama atau akidah, seperti yang terjadi pada agama katolik dan protestan. Selain lahir dalam situasi konflik, gerakan fundamentalisme agama juga diawali dengan pemahaman mereka terhadap teks-teks suci keagamaan secara harfiah (literal) (Grose, 1998). Epistimologi agama bagi mereka yang fundamentalis selalu dipahami bersifat konfliktual, sehingga secara mental mereka merasa dalam bahaya dan siap mati untuk perang melawan musuh yang berbeda keyakinan atau agama.

Pandangan ini tetap hidup dalam kelompok sempalan beberapa agama dan semuanya berakar pada fundamentalisme dalam penghayatan agama. Secara teoritis, fundamentalisme muncul dalam bentuk aksi penolakan, perlawanan, dan keinginan dari komunitas tertentu agar dunia ini diubah dan ditata sesuai dengan doktrin agamanya. Karena itulah, bentuk-bentuk fundamentalisme agama yang dipraktikkan oleh sebagian umat beragama seharusnya tidak sampai menghadirkan ancaman bagi masa depan kehidupan.

Dari beberapa pernyataan di atas, dapat diambil suatu pemahaman bahwa selama manusia ada maka agama pun akan tetap terus eksisten dalam kehidupannya, terlepas adanya interpretasi akan adanya berbagai pendapat dan sikap orang terhadap agama, yang jelas peranan agama dalam perkembangan dewasa ini masih tetap hidup dan tradisi yang dilahirkannya terus dijaga dan dibela oleh pemeluknya dari zaman ke zaman. Bahkan tidak sedikit ada yang membela dengan cara "mengangkat pedang dan/atau menanam bom" sekalipun.

Dalam setiap ekspresi keagamaan sesorang pasti memilki titik diversitas, hal ini memungkinkan mereka memiliki frame berpikir yang dipengaruhi oleh faktor internal maupun eksternal yang membentuk, sehingga di antara mereka ada yang memiliki kecenderungan berpikir eksklusivisme, inklusivisme, pluralisme ataupun universalisme. Fenomena ini tidak dapat

kedatangan Yesus kembali. Dalam kerangkan kesempurnaan Alkitab itulah mereka mengkritik dan melawan banyak aspek kehidupan modern seperti pluralisme, konsumerisme, materialism dan penekanan pada persamaan laki-laki dan perempuan.. 
dipungkiri, mengingat dalam konteks Jakarta, persoalan agama menjadi primadona semenjak orientasi kepemimpinan di Jakarta mengangkat isu-isu kebudayaan lokal yang secara perlahan mampu membuka kran konflik masyarakat agama di Jakarta.

Dalam tatanan teologis, begitu banyak anjuran untuk membangun kohesi sosial. Pada tataran sosiologis, Parsons misalnya mengatakan bahwa agama secara universal dipandnag sebagai komponen utama dalam integrasi sistem nilai. Dengan kata lain, agama menjadi sebuah energi besar dalam cita-citanya membangun integrasi sosial. Dengan dasar pemikiran tersebut, jika digunakan perspektif Durkheim, maka agama dijadikan sebagai sumber pembentukkan keyakinan yang mengikat kehidupan bersama dalam ritual dan pengalaman keagamaan yang sakral (Maliki, 2010). Turner pun menyatakan religion is a social cement, binding individuals and social group into a communal order (Turner, 2012).

Namun dalam banyak kasus yang terjadi adalah justru konflik keagamaan yang muncul. Nilai agama tidak tertransformasikan sebagai energi positif justru sebaliknya seakan menjadi faktor political liability atau ongkos politik yang besar (Maliki, 2010). Melihat yang terjadi di Jakarta khususnya di mana konflik terjadi antara agama dan pemerintah, yakni ketika pemerintah sangat kuat di bawah kepemimpinan Gubernurnya (Red; Ahok). Kekerasan antar agama dan bahkan juga konflik kekerasan terjadi dalam satu denominasi agama yang sama. Melihat hal demikian, akar konflik teologis maupun sosiologis agama tidaklah memuat pesan dan tata nilai kolektif yang dibutuhkan masyarakat sebagai modal sosial dikarenakan pola pemahaman atau konstruk manusia terhadap agama tidak utuh.

Munculnya sejumlah gerakan atau tindakan fundamental mengatasnamakan agama di Jakarta pun sebenarnya tidak lepas dari respon mereka terhadap perkembangan struktural ekonomi politik yang terjadi selama ini. Mereka memandang modernisasi ekonomi dan politik yang terjadi tidak memungkinkan tumbuhnya partisipasi secara plural.

Dalam merespon tekanan struktural tersebut sebagian memang memilih jalan akomodasionis, sebagian lagi reformis, dan sebagian lagi memilih jalan fundamentalis. Fundamentalisme agama dimaknai sebagai perlawanan atas tekanan refresif yang mengancam sumber-sumber eksistensial ekonomi, politik maupun keagamaan mereka (Turner, 2012).
Pasca adanya desentralisasi dan terbukanya kran otonomi daerah, banyak sekali semangat pembaharuan di berbagai aspek termasuk dalam wilayah agama dan politik praktis pemilu (Ahmad Suaedy, 2007). Semenjak berlakunya otonomi daerah dengan sistem desentralisasi, Pemilu di sejumlah daerah di Indonesia selalu disertai dengan sejumlah kecemasan akan munculknya konflik. Demikian pula dalam pilkada Jakarta. Ada beberapa penyebab mengapa masyarakat memanfaatkan penyelenggaraan pemilu sebagai tempat memunculkan kekecewaan terbuka, dan bahkan memunculkan konflik yang menggunakan tindakan kekerasan. Dalam hal ini kita menggunakan penjelasan Robert T.Gurr (1974) mengenai teori deprivasi relatif. Masyarakat yang terkena pengaruh deprivasi relatif akan mudah tergoda untuk melakukan tindakan kekerasan, dan menggunakan instrumen apa saja yang dianggap dapat mendukungnya (Maliki, 2010). Kampanye dengan mobilisasi massa, adalah instrumen yang paling bagus untuk mengekspresikan kekecewaan. Sesuai dengan karakteristik massa yang "anonym", hilang rasa tanggung jawab dan kesadaran pribadi, maka pada saat seperti itu akan dengan mudah muncul solidaritas perkwanan yang sensitif dan emosional (Maliki, 2010).

Munculnya sejumlah gerakan atau tindakan fundamental mengatasnamakan agama di Indonesia pun sebenarnya tidak lepas dari respon mereka terhadap perkembangan struktural ekonomi politik yang terjadi selama ini. Mereka memandang modernisasi ekonomi dan politik di negeri ini tidak memungkinkan tumbuhnya partisipasi secar aplural. Depolitisasi agama telah terjadi di mana-mana, bahkan berlangsung sedemikian intensif sampai pada tataran pelarangan penggunaan sejumlah simbol keagamaan di ranah publik. Depolitisasi agama itu akan berimplikasi kepada peminggiran masyarakat agama dalam aspek kehidupan yang luas, termasuk dari kehidupan ekonomi.

Dalam merespon tekanan struktural tersebut sebagian memang memilih jalan akomodasionis, sebagian lagi reformis, dan sebagian lagi memilih jalan fundamentalis. Fundamentalisme agama dimaknai sebagai perlawanan atas tekanan refresif yang mengancam sumber-sumber eksistensial ekonomi, politik maupun keagamaan mereka (Maliki, 2010). Dalam penelitiannya terhadap perilaku masyarakat di kawasan kumuh Bulak Banteng, Surabaya, Fachry Ali melihat adanya tindakan brutalisme atau kekerasan ekonomi yang 


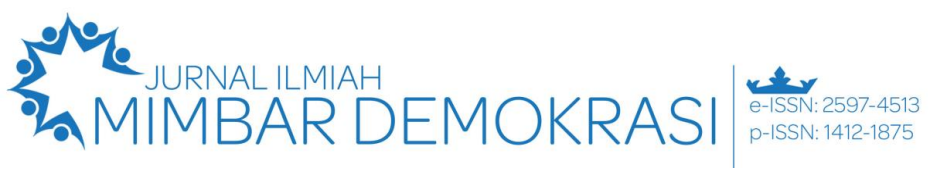

\section{Vol. 19 No. 2 Tahun 2020 | Hal. 12 - 27}

dilandasi semangat "agenda suci" keagamaan mereka. Bahkan dalam peneltiannya itu telah terjadi konflik komunal masyarakat agama (Aly, 1996). Maka tidaklah mengherankan jika doktrin agama mengajarkan untuk menebar kasih sayang (afsus salam) dan kasih untuk sesama (love thy neighbor), tetapi mereka tak segan terlibat dalam praktik kekerasan, tentu mengatasnamakan sebuah "agenda suci" (Smith, 1985).

Dengan demikian, realitas objektif dalam hal tertib sosial atau kehidupan masyarakat, apapun bentuknya, merupakan hasil refleksi manusia dalam memahami agama yang diyakini. Pemahaman atas nama agama seperti itu didasarkan kepada pandangan Peter L. Berger yang menyatakan bahwa agama melahirkan makna stabil dan berfungsi sebagai langit suci (sacred canopy) yang senantiasa digunakan aktor untuk mengorganisasikan dan menata struktur kehidupan (Berger, 1991). Dan bagi masyarakat yang berada dalam puncak pelapisan sosial, agama acapkali tidak dipahami sebagai instrumen pembebasan dan pemberdayaan, melainkan lebih mudah dimengerti dan dipraktekan menjadi sebuah instrumen legistimasi bahkan dominasi. Agama tidak dijadikan sebagai payung suci terkait erat dengan urusan dan kehendak manusia berkuasa melainkan dipraktekan sebagai alat untuk mempertahankan kekuasaan tersebut.

\section{Dinamika politik masyarakat beragama \\ Dalam permasalahan "Aksi Bela Islam"} yang terjadi pada serangkaian peristiwa demonstrasi beberapa tahun lalu 2016, 2017, terlihat berbagai organisasi kemasyarakatan Islam seperti FPI, MMI, HTI, PII, PUI, HMI dan lainnya sebagainya. Meskipun GNPF-MUI telah menempuh jalur hukum, namun gerakan sosial pada "Aksi Bela Islam" tetap menjadi semacam kelompok garis depan dan keras dalam menuntut proses hukum kasus penistaan agama yang terjadi. dengan aksi demonstrasi yang mendorong berbagai unsur aparatur negara agar berperan aktif melakukan kebijakan sesuai moral dan tegas dalam penegakan hukum. Bahkan dalam "Aksi Bela Islam" tersebut, GNPF-MUI dinilai mampu memobilisasi massa Islam dari berbagai kelompok Islam dan lainnya. Massa Islam dari berbagai daerah Indonesia berangkat ke Jakarta untuk Aksi Bela Islam tersebut.

Berdasarkan permasalahan di atas, GNPFMUI terutama peserta "Aksi Bela Islam" jika dalam pembagian kelompok beragama yang dilakukan Willian James, antara jiwa sehat (bealthy mindedness) dan jiwa yang sakit (sick soul).
Pengikut aksi ini memiliki kecenderungan penuh gairah, terlibat, bersemangat tinggi, dan meluap dengan vitalitas di mana terlihat saat dilakukan demonstrasi. Ciri lain optimistis, bahagia dan spontan, dari kasus "Aksi Bela Islam" yang dilakukan, terlihat pengikut aksi ini dengan lantang dan percaya diri (optimis) menyatakan penista agama harus dihukum, selain itu terlihat dalam "Aksi Bela Islam”, banyak pengikut aksi yang mengaku menangis terharu (bahagia) saat melakukan aksi ini, ditambah setelah ditetapkannya penetapan tersangka kasus penistaan agama, sekalipun belum dipenjara.

Lebih lanjut, pembedaan yang dibuat oleh James menciptakan kecenderungan (trend) dalam menafsirkan agama sebagai bentuk-bentuk institusional atau kelembagaannya. Dalam penafsiran ini dibedakan dua kelompok penganut agama. Kelompok pertama adalah para penganut agama yang menghayati agama secara formal dan berdasarkan kebiasaan. Kelompok kedua adalah para penganut agama yang memandang agama, tepatnya iman, sebagai keterlibatan yang disadari.

Dalam pandangan ini, "Aksi Bela Islam" yang tergabung dalam GNPF-MUI termasuk dalam kategori kelompok penganut agama yang memandang agama, tepatnya iman sebagai keterlibatan yang disadari. Namun, dalam permasalahan agama intrinsik dan agama ekstrinsik terutama pada permasalahan "Aksi Bela Islam" yang dilakukan, GNPF-MUI cenderung berada dalam kategori agama ektrinsik saat permasalahannya mengarah ke politik, karena jelas tujuan aksi ini harusnya bukan agenda politik. Terlepas dari bagaimana prinsip dan misi yang diusung GNPF-MUI, permasalahan ini akan memperlihatkan GNPFMUI teramasuk ektrinsik saat dimana aksi ini dibarengi motif tujuan (orientasi) atau agenda politik. Walaupun memang dalam membahas agama ektrinsik dan agama intrinsik, setidaknya akan ada dua kepentingan yang berbeda, yakni kepentingan pribadi atau kepentingan nilai yang ada dalam agama. Saat kepentingan pribadi di atas kepentingan nilai agama saat itulah disebut agama ekstrinsik, begitupun sebaliknya saat kepentingan pribadi di bawah kepentingan nilai agama maka disebut agama intrinsik.

Dalam "Aksi Bela Islam" yang dilakukan terlihat aksi ini disusupi orientasi politik sebagaimana setelah Aksi Bela Islam II (411) pada 4 November 2016, intelijen Polri dan TNI telah mendeteksi bahwa aksi unjuk rasa besar-besaran lanjutan ("Aksi Bela Islam III") yang diselenggarakan oleh GNPF-MUI pada 2 
Desember 2016 (212) telah disusupi dengan agenda terselubung untuk melakukan aksi makar terhadap pemerintah Republik Indonesia (H.T, 2016). Bahkan sebelumnya dalam aksi 4 November 2016 diikuti politukus bernama Fahri Hamzah, yang pada saat itu berstatus sebagai wakil ketua DPR RI, ikut berorasi, yang mana dalam orasinya diduga berisi penghasutan, yakni memberitahukan cara menjatuhkan Presiden Joko Widodo, lalu menuding presiden telah melanggar hukum berkali-kali (Martahan Sohuturon, 2016). Dari hal tersebut menjadi semakin terbukti adanya orientasi politik dalam "Aksi Bela Islam" yang dilakukan, ditambah dengan pemberitaan di media massa ditangkapnya orang-orang yang diduga akan melakukan makar dengan memanfaatkan "Aksi Bela Islam”, menjelang aksi bela Islam III (212) pada dini hari tanggal 2 Desember 2016 oleh pihak kepolisian (Anonimous, 2016b).

Orientasi politik dalam "Aksi Bela Islam" semakin lebih jelas, dimana di dalam situs web resmi FPI, dimuat sebuah artikel yang menyatakan "Ingat...Ingat...!!! Partai pendukung Ahok haram dipilib di seluruh NKRI karena mendukung penista agama" (Anon, 2016). Terlihat bagaimana organisasi ini terlibat dalam kampanye terselubung menjelang pilkada DKI Jakarta 2017, yang mana Ahok saat itu ikut mencalonkan menjadi gubernur dalam pilkada DKI Jakarta.

Selain itu, mencermati sikap keagamaan yang dilakukan para demonstran, dapat disimpulkan bahwa sikap dari organisasi ini termasuk bersikap prasangka (prejudice). Diketahui saat-saat sebelum "Aksi Bela Islam II dan III" di media sosial terjadi banyak ajakan, isu, provokasi ataupun hasutan untuk mengikuti ataupun menolak aksi bela Islam yang dilakukan. Sebagai contoh, dalam akun twitter Habib Rizieq dari FPI menganjurkan perusahaan, kantor dan sekolah untuk diliburkan agar pegawai dan pelajar ikut aksi tersebut. Dan juga dalam situs resmi FPI yang menyuarakan untuk "Aksi Bela Islam" dalam bentuk brosur artikel yang berisi "GNPF-MUI, Seruan Jihad Konstitusional Bela Agama \& Negara, Ikutilah !!! Aksi Bela Islam II “Ayo Penjarakan Ahok !!!” Karena Menista Agama, Menodai al-Qur'an, Melecebkan Ulama, Menghina Umat Islam, Ini Bukan Aksi SARA \& politik Pilkada tapi ini Aksi Penegakan Hukum, Waktu: Jum'at 4 November 2016 Shalat Jum'at di Istiqlal, Long march: Dari masjid Istiqlal ke Istana Presiden RI, catatan..... Waspadai Penggembosan Aksi Hati-Hati Provokasi" (Anonimous, 2016a).
Situasi politik ini sebenarnya memberi banyak peluang dan harapan. Peluang bagi lahirnya figur-fgur Islam yang diharapkan sekaligus tampilnya gagasan Islam seperti yang diingankan.

Perbincangan kaitan antara agama dan berbagai macam persoalan keduniaan termasuk politik sering menimbulkan kontroversi. Dalam hal ini, paling tidak ada dua pandangan besar yang tidak saja berbeda, tetapi juga bertolak belakang. Yang pertama adalah pandangan bahwa agama tidak dapat dipisahkan dari masalah-masalah keduniaan, apakah itu sosial-budaya, ekonomi, maupun politik. Karenanya, antara agama dan persoalan keduniaan tersebut ada kaitan formal. Tentunya bagi orang beragama, argumen ini tidak pantas kiranya memisahkan persoalan-persoalan dunia dari agama. Yang kedua adalah pandangan bahwa bukan saja agama itu berbeda dengan persoalan keduniaan, tetapi antara keduanya tidak ada hubungan sama sekali, dan karenanya harus dipisahkan. Perdebatan seperti itu biasanya diikuti dengan munculnya penilaian-penilaian yang sifatnya judgmental kepada masing-masing pendukung pandangan di atas. Mereka yang mendukung pandangan yang pertama sering diasosiasikan sebagai pemeluk agama yang skriptualis atau fundamentalis. Sedangkan mereka yang mendukung pendapat yang kedua biasanya dihubungkan dengan sikap hidup sekuler (Effendy, 2000).

Namun tidak semua pernyataan bahwa agama dan politik memiliki keterkaitan seperti yang dibenarkan oleh sebagian pihak di atas tadi, karena bagi beberapa orang di antaranya ada pendapat yang mengemukakan bahwa tidak ada keterlibatan agama dalam politik praktis, pendapat ini menganggap bahwa politik memiliki wilayah yang berbeda, bahkan berseberangan dengan agama (Kahmad, 2011). Karenanya agama merupakan persoalan pribadi (Private), sedangkan politik adalah hal lain di luar urusan agama. Menurut Bahtiar Effendy bagi mereka yang mendukung atas pandangan bahwa agama tidak dipisahkan dari persoalan keduniaan baik sosial, budaya, maupun politik diasosiasikan sebagai pemeluk agama yang skriptualis atau fundamentalis, sedangkan mereka yang mendukung pendapat bahwa agama sama sekali tidak memiliki keterkaitan dan karenanya harus dipisahkan adalah mereka yang memiliki sikap hidup sekluer.

Namun yang ingin ditekankan adalah bahwa agama bukanlah sesuatu yang pada dasarnya bersifat pribadi melainkan publik. Seperti yang 


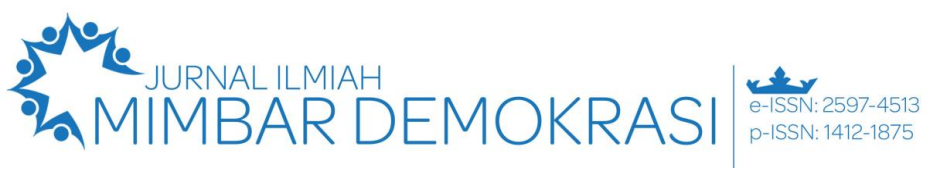

Vol. 19 No. 2 Tahun 2020 | Hal. 12 - 27

dikemukakan sosiolog terkemuka Robert $\mathrm{N}$. Bellah sebagai agama sipil dan Jose Casanova yang menyebutkan sebagai sesuatu yang civic (publik) atau deprivatized (tidak bersifat pribadi). Dengan demikian, secara teologis maupun sosiologis, agama dapat dipandang sebagai instrument Illahiah untuk "memahami" dunia. Secara omnipresent agama mampu "hadir di manamana" melalui simbol-simbol atau nilai-nilai yang dikandungnya. Dan begitu pula secara sosiologis, tidak jarang agama pun menjadi faktor penentu dalam proses transformasi dan modernisasi kehidupan.

Dalam kurun waktu yang panjang, keterkaitan agama dan politik menjadi persoalan yang menarik, bahkan interplay antara agama dan politik juga semakin mengental. Seperti yang dilihat oleh beberapa sosiolog, hubungan antara agama dan politik kini tengah bergerak ke "kanan", seperti halnya di Spanyol, Brazil dan Amerika Serikat menurut Richard Falk sebagai "politically enganged spirituality" merupakan fenomena yang sedang berkibar (Kahmad, 2011). Pertalian agama dengan politik seperti ini tidak terjadi dalam bentuknya yang konstruktif, sebagian bisa terjadi karena terekspresikan dalam pola-pola simbolistik dan formalistik. Karenanya menurut Bahtiar Effendy hal ini dapat menimbulkan konflik atau ancaman dan bukan rahmat.

Hubungan antar variabel politik dan agama inilah yang kemudian menjadi perhatian publik, karena banyak variabel agama dan politik ini secara bersama-sama diperankan oleh sejumlah tokoh dan pemuka agama (Muhtadi, 2008). Ketika hubungan keduanya terjadi dalam masyarakat yang memiliki sensitifitas agamanya tinggi, maka suhu politik menjadi semakin panas. Sejumlah kasus yang berkaitan dengan fenomena pemanfaatan agama sebagai saluran potensial dakwah politik yang diperankan para tokoh agama. Persoalan yang berkenaan dengan person sosial politik pemuka agama tersebut dapat menjadikan isu agama sebagai salah satu bentuk saluran potensial komunikasi politik (Muhtadi, 2008).

Banyak orang menanggapi isu dan saluran komunikasi alternatif dengan cara yang berbedabeda. Pandangan politik semacam ini mendapat penolakan dari model klasik warga demokratis yang menyimpulkan bahwa ketika orang menanggapi isu: (1) orang lebih cenderunng menanggapi komunikasi danmerumuskan atau mengubah pandangan mereka jika isunya relatif baru, tak berstruktur atau jauh dari mereka; (2) komunikasi mengenai isu lebih efektif pada isu sampingan ketimbang isu pokok, semakin penting isu itu bagi seseorang maka semakin besar kemungkinan opini orang itu tetap stabil dalam menghadapkan argumentasi yang bertentangan; (3) komunikasi mengenai isu sebagai isu lebih kecil kemungkinan efektifnya dibandingkan dengan komunikasi mengenai personal sebagai isu (Nimmo, 2010).

Tidaklah mengherankan juga ketika banyak kegiatan keagamaan yang bernuansa politik diadakan hanya sekedar untuk menarik simpati suara masyarakat beagama sebagai pemilih, seperti pada kegiatan peringatan hari besar keagamaan, aktivitas pengajian dan sebagainya. Keterlibatan elite politik dalam memainkan peran agama dirasa mampu meningkatkan popularitas, serta akseptabilitas atau kelayakan untuk diterima dengan cara menyentuh sisi emosional umat beragama dengan maksud agar apa yang diinginkan dapat terwujud (Kahmad, 2011). Strategi semacam ini dinilai ampuh untuk mendongkrak suara pemilih yang dalam kategori belum rasional (Muchlis, 2008), karena masyarakat Jakarta sebagai pemilih masih memiliki sensitivitas agama, sehingga mudah diajak jika menggunakan isu-isu yang berkaitan dengan agama.

Harus diakui, persoalan "Aksi Bela Islam" tidaklah sesederhana yang kita duga. Bukan karena sulitnya melihat relasi antara aktor penggerak aksi dengan elit politik yang mempunyai kepentingan dibaliknya. Melainkan, karena makin kaburnya peta kelompokkelompok Islam yang terlibat di dalam kegaduhan ini. Dengan ini tidak bisa dikatakan bahwa para pendukung aksi massa sebagai "Islam Fundamentalis Sunni" karena dikomandoi oleh FPI. Karena buktinya, tidak sedikit yang terlibat dalam aksi adalah mereka yang biasa dikelompokkan ke dalam Islam moderat seperti NU.

Bahkan, banyak kyai dan santri NU yang terlibat di dalamnya. Berada pada posisi ini, misalnya, Kyai Ma'ruf Amin. Selain menjabat sebagai ketua Majelis Ulama Indonesia (MUI), beliau juga menjabat sebagai Rais Am PBNU yang merupakan pucuk tertinggi dalam struktur PBNU. Atau kiai Salahudin Wahid, pengasuh pesantren Tebuireng, Jombang, Jawa Timur. Bagaimana kita akan mengkategorikan kedua aktor tersebut? Apakah bisa disebut sebagai Islam fundamentalis karena turut menyerukan perjuangan "Aksi Bela Islam" atau sebagai Islam Moderat karena keduanya orang penting di 
lingkungan NU, yang oleh banyak pengamat Islam Indonesia dianggap sebagai representasi Islam Moderat? Maka, pada kasus "Aksi Bela Islam", kategori-kategori yang sudah mapan seperti fundamentalis, moderat, intoleran, toleran, demokratis dan anti demokrasi menjadi sangat kabur dan tidak lagi terang batasannya.

Meski demikian, jika dipetakan secara sederhana posisi dominan antar kelompok Islam yang terlibat dalam pro dan kontra "Aksi Bela Islam" setidaknya ada dua: Pertama, Islam Politik sebagai pendukung utama aksi. Mereka menganggap apa yang sedang diperjuangkannya sebagai kewajiban moral (moral obligation) yang harus ditanggung oleh semua kaum muslim. Bahkan, salah satu argumen para kyai dan santri yang berafliasi pada NU, yang terlibat dalam "Aksi Bela Islam" mendasarkan perjuangannya pada pernyataan pendiri NU, Hadratus Syekh Hasyim Asy'ari, yang kurang lebih menganjurkan umat Islam untuk turut membela agama Islam dan sekuat tenaga berusaha menangkis atau menolak orang yang menghina al-Quran dan sifat-sifat Allah.

Pernyataan tersebut akan menjadi sangat problematis jika dipahami secara harfiah. Seandainya dipahami secara substansial, maka "Aksi Bela Islam" sebagaimana yang tengah berlangsung tak akan pernah terjadi. Bukankah kita sendiri, umat Islam, yang justru seringkali menghina al-Quran karena tidak mampu mengamalkannya dalam praktik hidup sehari-hari secara total dan konsekuen? Mungkin, apa yang sedang diperjuangkan dalam "Aksi Bela Islam" tidaklah substansial, bahkan berpotensi besar mereduksi ajaran Islam mengenai kemanusiaan yang bernilai universal. Namun kita juga tidak boleh naif dengan menganggap aksi semacam ini sesuatu yang homogen. Semua pihak yang terlibat di dalamnya membawa kepentingannya masingmasing dengan perekat utamanya adalah dugaan penistaan agama.

Kedua, Islam Moderat, sebagai penolak utama aksi. Penilaian Islam Moderat pada aspek teologis, dalam melihat "Aksi Bela Islam" meskipun tepat, sayangnya masih terjebak pada penilaian esensialis. Melalui cara pandang semacam ini, Islam Moderat tidak bisa melepaskan diri dari prasangka yang dibangunnya sendiri yaitu bahwa setiap aksi massa, apalagi ketika diusung oleh pihak yang terlanjur dilabeli sebagai Islam fundamentalis, otomatis akan terjadi kerusuhan, atau berefek negatif secara sosial dan politik. Maka wajar jika kita dapati tanggapan mereka terhadap aksi massa cenderung alergi dan sinikal.

Praktik penggunaan isu-isu agama dalam politik sangat bervariasi, baik simbol, tempat, maupun statement yang digunakan. Dalam konteks ini, penggunaan isu agama dalam kampanye dilandasi keyakinan bahwa masyarakat akan memberikan pilihan politiknya kepada pasangan calon yang yang memiliki kualitas keberagamaan yang baik dan benar. Untuk itu, setiap pasangan calon berupaya mencitrakan dirinya sebagai yang agamis, bahkan kalau perlu memanipulasinya (Kahmad, 2011). Betapa pun politik mampu memainkan peran agama dalam kehidupan masyarakat, politik akan terus melahirkan pertentangan atau ketidaksepakatan. Hanya saja temperatur pertentangan tersebut kadang melemah kadang menguat, tergantung dinamika politik, di mana tingkah laku pihak yang berkuasa terhadap lawan politiknya sangat menentukan suhu pertentangan tersebut (Mintarja, 2011).

Selain itu, masih banyak penggunaan isu-isu agama dalam perhelatan politik Pilkada Jakarta, baik secara simbol atau pun statement yang digunakan setiap pasangan calon. Jika digunakan perspektif teori dramaturgi, perilaku politik setiap pasangan calon dapat dilihat dari sebagai drama sehingga tindakan manusia bergantung pada waktu, tempat dan audiensi yang dihadapi (Kahmad, 2011). Praktik kampanye yang dilakukan melalui aktivitas keagamaan misalnya, menjadikannya sebagai wahana front stage tempat para pasangan calon akan berhadapan dan dilihat oleh masyarakat agama, hal ini dilakukan sebagai bagian dari tuntutan peran (expectation and role) yang dimainkan. Sementara di luar momen kampanye (back stage) para pasangan calon bisa keluar dari citra dan skenario yang dimainkan dalam setiap kampanye (Kahmad, 2011).

\section{Analisis Hasil; Latar Belakang dan Dampak Aksi Bela Islam}

Fenomena "Aksi Bela Islam" yang terjadi pada momentum Pilkada DKI Jakarta dewasa ini, menunjukkan adanya dinamika atau pun gelombang gerakan sosial masyarakat beragama. Jika menggunakan perspektif sosiologi dapat memudahkan dalam pembahasan ini. Pasalnya, perspektif ini mencoba mendalami tentang hakikat dan berbagai sebab terjadinya keteraturan pola pikiran dan tindakan manusia yang berulangulang sebagai bagian dari anggota suatu kelompok masyarakat (Kahmad, 2011). Salah satu di antara yang berkaitan dengan pola pikir dan tindakan manusia tersebut adalah faktor 


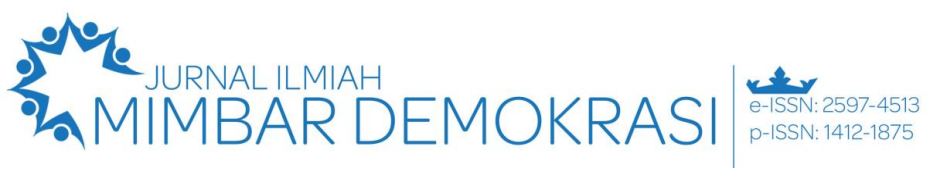

Vol. 19 No. 2 Tahun 2020 | Hal. 12 - 27

keagamaan, politik dan budaya mereka dalam sistem sosial. Untuk memulai pembahasan tersebut, perlu melihat konteks struktural-historis dari kemunculan aksi tersebut dan profil sosiologis itu sendiri.

Sosiologi agama (Hidayat, 2012)5 secara khusus memfokuskan pada kajian tentang perilaku masyarakat beragama, bukan hanya pada kebenaran ajaran agamanya saja. Sosiologi agama menyelami alam pikiran penganut agama yang dikajinya tanpa harus mengidentifikasi dirinya dengan agama yang dikajinya (Kahmad, 2011). Di samping itu, memahami sosiologi agama berarti menciptakan suatu risalah tentang agama di dunia modern (Turner, 2012). Pemahaman makna yang diberikan dalam bidang ini adalah pemahaman masyarakat tertentu pada sistem agamanya sendiri yang mencakup hubungan agama dengan struktur sosial, dan hubungan agama dengan aspek budaya, bukan agama, seperti magi, sains dan teknologi. Salah seorang yang memberikan sumbangannya dalam bidang sosiologi agama ini adalah Emile Durkheim, yang menempatkan masyarakat pada posisi utama atau yang sakral sedangkan di luar hal masyarakat adalah profan. Durkheim mengklaim, tanpa adanya masyarakat, maka tak satu pun yang akan muncul dalam kehidupan kita, termasuk agama (Pals, 2011).

Berbeda halnya dengan sosiologi politik, menurut Tom Bottomore dalam Political Sociology (1979) menyebutkan bahwa sosiologi politik selama ini mengkaji "power" atau kekuasaan dengan berbagai konsepnya yang beragam, termasuk perhatiannya yang hampir sama seperti otoritas, pengaruh, kekuasaan dan atau kekerasan. Lebih lanjut Bottomore memaknai sosiologi politik sebagai perdebatan tentang peran Negara dan relasinya dengan kewargaan (civil society) dan determinasi dalam transformasi masyarakat menuju demokrasi (Maliki, 2010). Di samping itu, dalam kaitan dengan relasi politik dan agama, sosiologi politik juga mengkaji transformasi masyarakat melalui pendekatan sekuler, organik dan yang memilih melakukan diferensiasi antara sekuler dan organik (Maliki, 2010). Menurut Kuntowijoyo, Islam sendiri mengakui adanya diferensiasi dan bahkan polarisasi sosial (Koentowijoyo, 1991).

Objek kajian sosiologi politik terbelah antara mereka yang memfokuskan kepada transformasi masyarakat dengan memilih jalan revolusi industri seperti halnya yang diikuti oleh Pareto dan Mosca dan Perspektif Marxian yang memilih menekankan kepada pentingnya analisa klas dalam sebuah formasi sosial, dan kajian sosiologi politik dengan memilih fokus kajian revolusi demokrasi. Bottomore memiliki kecenderungan bahkan tertarik pada pentingnya stabilitas dan mengabaikan masalah-masalah yang berkaitan dengan dengan perubahan, sebagaimana dapat diikuti dalam pemikiran Durkheim, atau Huntington dalam politik (Maliki, 2010). Akan tetapi, ada pula sosiolog yang memberikan pandangan bahwa justru instabilitas dan perubahan diabaikan adalah tema yang tidak bisa dielakkan dari proses transformasi politik di masyarakat macam apapun.

Betapapun agama dan politik memiliki wilayah kerja masing-masing, tetapi keduanya hidup dalam sosio-kultur masyarakat yang menjadikan keduanya sebagai bagian yang sulit untuk dihapuskan. Dalam pengalaman sejarah manusia, sekali-kali pernah kita jumpai ketidakharmonisasn antara berbagai kegiatan budaya manusiawi. Bahkan sebaliknya, sering kali terjadi pertarungan terus menerus antara berbagai kekuatan yang saling bertentangan. Misalnya pemikiran ilmiah bertentangan dan mendepak pemikiran mistis, begitu pun ketika mencapai puncak etis dan teoritisnya, agama perlu mempertahankan kemurnian cita-citanya, menentang sesuatu yang bukan terlahir dari rahimnya, termasuk politik dan khayalan yang melingkupi mitos. Antagonisme semacam ini tidak seutuhnya dibenarkan, karena bagi sebagian pendapat menyatakan bahwa sejatinya agama merupakan hal yang senantiasa bersentuhan dengan lingkungan sosial seharusnya menjadikan apa yang ada di luar dirinya sebagai bagian integral dari suatu agama. Demikian agama tidak lagi menjadi persoalan privat yang hanya sekedar melakukan proses ritual vertikal semata, tetapi diperlukan ritual-ritual horizontal yakni dalam persinggungannya dengan dunia sosial termasuk persoalan politik.

Selama persentuhannya dengan politik, agama senantiasa mengalami perkembangan yang cukup signifikan. Hal ini terbukti dari banyaknya orang-orang atau masyarakat yang beragama terlepas agama apa yang mereka anut atau
5 Agama secara gramatikal adalah tidak kacau, lebih lengkap menurut Wuraish Shihab dalam kata pengantar buku Agama Punya Seribu Nyawa, mendefiniskan agama sebagai hubungan manusia dengan satu kekuatan yang jauh melebihinya dimana manusia patuh kepada kekuatan itu yang kemudian makna "kekuatan" ditekankan pada Sang pencipta alam, yakni Tuhan. 
percayai menurut keyakinannya itu. Semisal di Indonesia, agama Islam menjadi agama mayoritas penduduknya. Tentu hal semacam ini tidak dapat dilepaskan dari besarnya pengaruh yang diberikan Islam bagi bangsa Indonesia, dan juga proses transformasi politik dalam memasyarakatkan Islam di tanah Indonesia ini. Akan tetapi apakah keuntungan yang didapatkan agama dalam memainkan percaturan politik tersebut berdampak nyata pada perilaku politik seseorang dalam menjadikan agama sebagai basis atau spirit perubahan sosial dengan jalan untuk mendapatkan keinginan bagi para pemangku kepentingan politik.

"Aksi Bela Islam" adalah sebuah kenyataan. Peristiwa tersebut menyegarkan kembali imajinasi politik bangsa bahwa gerakan Islam di Indonesia saat ini masih menunjukkan eksistensinya, sekalipun berada pada posisi yang tertekan dalam partai politik. Termasuk yang maujud ke dalam rentetan aksi massa yang terjadi di tengah kondisi politik DKI Jakarta saat ini yang begitu panas. Salah satu hal yang menjadi alasan munculnya gerakan sosial ini ialah ketika identitas agama mereka terusik. Umat hanya mudah terbakar emosi ketika seorang non-Muslim menghina ayat al-Quran dan akan merasa paling beriman ketika menuntut keadilannya dengan turun mengaliri jalanan bersama ribuan umat sesamanya yang diperintahkan oleh sebuah fatwa yang dikeluarkan MUI (Majelis Ulama Indonesia).

Guncangan "Aksi Bela Islam" telah membuat banyak kalangan harus saling bertemu, berunding dan menegosiasikan kesepakatan, mulai dari soal aksi harus berjalan damai, tentang tuntutan hukum penodaan agama harus tuntas, hingga ditangkapnya sejumlah orang yang kena tuduhan makar. Hal ini yang kemudian mendorong Presiden Joko Widodo mengunjungi Prabowo Subianto, mantan musuhnya saat pemilihan presiden 2014, dalam rangka mengurangi kemungkinan ketegangan yang bakal terjadi selama aksi tersebut. Sementara itu, para tokoh senior TNI berspekulasi kemungkinan akan kekhawatiran lahirnya "Arab Spring", ini merujuk pada demonstrasi besar yang berlangsung di Timur Tengah yang mampu menurunkan rezim penguasa. Sedangkan analis lain mengingatkan kemungkinan "Aksi Bela Islam" tersebut disusupi oleh para simpatisan ISIS.

Identitas politik kini menemukan suasana baru yang bertarung dan beradu kekuatan dengan memanfaatkan aksi massa. Bahkan banyak analisis yang melihat ini sebagai gerakan yang harus diakui hasil dari kumpulan situasi konflik sosial yang kompleks. Hal ini bias saja disebabkan karena telah meningkatnya intoleransi dan ekstrimisme agama yang dibiarkan merajalela oleh pemerintah, dengan asumsi ketakutan akan "Islamic backlash" (pukulan balik dari kekuatan Islam). Atau sebagaimana yang diargumentasikan oleh ahli lain, bahwa "Aksi Bela Islam" hanyalah kasus elit politik yang memobilisasi massa sebagai bagian dari strategi menjelang Pilkada (An, 2016).

Sandaran "Aksi Bela Islam” tersebut adalah penghinaan, hujatan dan pelecehan terhadap kitab suci umat Islam. Predikat sandaran ini dianggap yang layak didengungkan untuk merebut simpati massa yang selama ini dianggap memilih pasif dan diam. Setidaknya, "Aksi Bela Islam" telah menunjukkan kekuatan untuk untuk menumbuhkan kesadaran keagamaan yang meyakini bahwa mayoritas itu bukan sebuah angka statistik tapi kumpulan massa yang bisa digerakkan.

Pilar kekuatan yang terjadi pada peristiwa ini menjadi diperhitungkan ketika aparat mulai berusaha menegoisasi bahkan mencegah mobilisasi melalui berbagai cara. Larangan dari ulama maupun pimpinan ormas ternyata tak cukup manjur, bahkan himbauan dan larangan dari kepala daerah juga tak mempan. Larangan tak hanya berhasil ditangkis, tetapi juga meningkatkan antusiasme massa untuk ikut terlibat. Lautan massa pada "Aksi Bela Islam" tersebut telah menciptakan banyak kisah "ajaib" yang mampu mempererat keyakinan atas apa yang mereka harapkan. Harapan pada pemerintah untuk menghukum Ahok hingga menuntut pemerintah untuk mendengar aspirasi mereka. Meskipun yang paling membuat bangga tidak lain adalah keyakinan baru bahwa kekuatan massa Islam tidak sekecil yang diduga. Ibarat ranting yang kini berusaha membuat pohon dengan melipat gandakan kesadaran atas keunggulan Islam dan bahkan mempercayai Islam sebagai perekat NKRI (Negara Kesatuan Republik Indonesia) yang semenjak dulu tetap bersaing dengan banyak ide-ide politik lainnya.

Apa yang terjadi pada Pilkada DKI Jakarta saat ini adalah agama dipakai sebagai alat kepentingan politik untuk menjegal salah satu pasangan calon Gubernur. Sekalipun belakangan ini banyak himbauan tentang "jangan bawa-bawa agama" atau "jangan gunakan agama" semakin mudah kita temukan dalam berbagai frasa. Bahkan setelah Ahok resmi menjadi cagub (calon gubernur) yang diusung Partai Demokrasi Indonesia Perjuangan (PDIP), frasa yang paling 


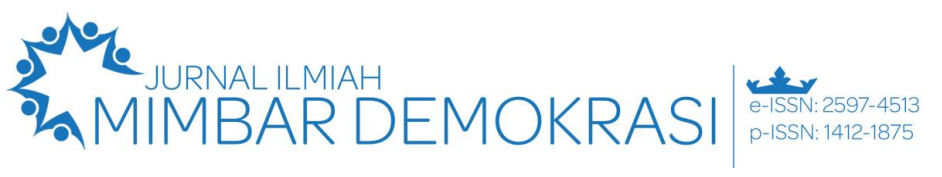

Vol. 19 No. 2 Tahun 2020 | Hal. 12 - 27

ramai diucapkan dari himbauan itu adalah “jangan gunakan Islam sebagai alat politik."

Bukan hanya para pendukung Ahok saja yang menggunakan himbauan ini untuk menjawab orang-orang yang menentang Ahok lantaran beragama Kristen. Beberapa penentang Ahok pun turut menggunakan himbauan semacam ini. Ali Taher, anggota DPR dari Partai Amanat Nasional (PAN) yang mengusung pasangan Agus-Silvy, misalnya, meminta Ahok "jangan menyalahgunakan simbol-simbol agama untuk kepentingan politik.". Artinya, himbauan ini dapat digunakan oleh siapa pun yang menganggap lawannya off-side dalam urusan agama dan politik. Persoalannya, bagi gerakangerakan Islam tertentu garis off-side ini tak pernah ada.

Sebagaimana dicatat oleh (Kumar, 2012), sejak awal abad ke 20, muncul gerakan Islam bertujuan politik mengembalikan supremasi Islam dari gerusan kolonialisme yang dipelopori oleh tokoh-tokoh muslim seperti Hasan Al-Bana dan Abul Ala al-Maududi. Gerakan yang kemudian di kenal sebagai Islam Politik ini sejak lama telah berada di Nusantara, menjadi bagian dari apa yang telah di pahami sekarang sebagai Islam Nusantara itu sendiri dan bisa melihat mereka ada dalam "Aksi Bela Islam" sebagai salah satu kekuatan dominan.

Ada banyak prasangka-prasangka tidak sehat yang dilancarkan terhadap gerakan Islamis. Salah satu yang paling sering dikemukakan di media sosial atau spanduk di jalanan adalah himbauan "tidak menggunakan Islam untuk politik", himbauan ini sama halnya dengan menghimbau "jangan gunakan oksigen untuk bernapas". Kondisi yang terjadi pada "Aksi Bela Islam" dianggap bahwa gerakan ini tidak pas dengan kondisi nusantara dan harus diasingkan ke Timur Tengah. Padahal ini merupakan pandangan yang sama membingungkannya, yang menganggap semua kekerasan berasal dari Arab dan harus dikembalikan ke Arab, ada pula prasangka merendahkan yang menganggap setiap "Aksi Bela Islam" tersebut merupakan kerumunan pengangguran yang mengharap nasi bungkus.

"Aksi Bela Islam" yang dilakukan oleh sejumlah elemen gerakan Islam, sepertinya semakin mengkonfirmasi penilaian tersebut. Gabungan dari berbagai ekspresi politik, mulai dari sentimen etno-religius yang puritan hingga

6 Dalam praktiknya, agama diapresiasi oleh masyarakat secara berbeda, berikut tipe-tipe masyarakat dan agama rasis-sektarian, kekecewaan politik, politik patronase elit, hingga ekspresi kelas, bercampur baur menjadi satu dan sulit terbedakan satu sama lain. Di sisi lain, peristiwa "Aksi Bela Islam" itu sebagai pertarungan antara "umat Islam" dengan "penguasa yang dzalim" atau, lebih parahnya lagi, "Cina Kafir".

Kecenderungan kultural dari motif tersebut sering dieksploitasi oleh kalangan elite politik dan tokoh agama yang terlibat dalam Pilkada. Maka tidaklah mengherankan ketika banyak kegiatan keagamaan yang bernuansa politik diadakan hanya sekedar untuk menarik simpati suara masyarakat beagama sebagai pemilih, seperti pada kegiatan peringatan hari besar keagamaan, aktivitas pengaiian dan sebagainya. Keterlibatan elite politik dalam memainkan peran agama dirasa mampu meningkatkan popularitas, serta akseptabilitas atau kelayakan untuk diterima dengan cara menyentuh sisi emosional umat beragama dengan maksud agar apa yang diinginkan dapat terwujud (Kahmad, 2011). Strategi semacam ini dinilai ampuh untuk mendongkrak suara pemilih yang dalam kategori belum rasional (Muchlis, 2008), karena masyarakat Jakarta sebagai pemilih masih memiliki sensitivitas agama, sehingga mudah diajak jika menggunakan isu-isu yang berkaitan dengan agama.

Sebagai masyarakat yang beragama, masyarakat Jakarta tidak dapat melepasakan segala bentuk perilakunya dari baju kebesaran yang disebut dengan "agama". Meminjam istilah Muammar Qadhafi yang dikutip oleh Endang Mintarja, bahwa peranan agama dalam kehidupan bernegara dapat menjadi landasan hukum nasional (Mintarja, 2011). Senada dengan ungkapan Benton Johnson, bahwa hal semacam ini dapat dilihat sebagai pertanda bangkitnya kesadaran kolektif masyarakat akan arti penting agama dalam kehidupan sosial, budaya, ekonomi dan politik Negara itu, karena agama dianggap dapat memberikan motivasi, dorongan dan stimulan bagi perubahan sosial yang diharapkan (Effendy, 2000). Demikian pula secara sosiologis, kadar keberagamaan masyarakat memiliki pengaruh pada perilaku politik masyarakat yang berbeda dengan masyarakat lainnya, karena semakin agama itu diyakini dengan keyakinan yang benar oleh penganut karakter seseorang akan "berwarna agama" lebih kental (Kahmad, 2011).6 Maka jika menggunakan analisa perspektif 
Durkheim, maka agama dapat dijadikan sebagai sumber pembentukan keyakinan yang mengikat kehidupan bersama dalam ritual dan pengalaman keagamaan yang sakral (Maliki, 2010). Meskipun pendapatnya ini tidaklah diamini secara mutlak, tetapi pesan yang disampaikan Durkheim menjadi salah satu Grand Theory dalam sistem perubahan sosial suatu masyarakat.

\section{Simpulan}

Setelah melakukan serangkaian kegiatan penelitian, mulai pengumpulan hingga interpretasi data lapangan, kesimpulan penelitian ini mengajukan beberapa kesimpulan berkaitan dengan pokok tentang pemahaman masyarakat tentang keterkaitan agama dan politik dalam dinamika Pilkada Jakarta.

Dari hasil temuan penelitian ini sebagaimana dipaparkan dalam bab-bab sebelumnya, dapat disimpulkan sebagai berikut. Pertama, "Aksi Bela Islam" menjadi sebuah kenyataan yang tidak terbantahkan. Peristiwa tersebut menunjukkan bahwa gerakan Islam di Indonesia saat ini masih menunjukkan eksistensinya dalam realitas politik bangsa, sekalipun berada pada posisi yang tertekan dalam partai politik. Termasuk yang maujud ke dalam rentetan aksi massa yang terjadi di tengah kondisi politik DKI Jakarta tersebut.

Salah satu hal yang menjadi alasan munculnya gerakan sosial "Aksi Bela Islam" tersebut ialah ketika salah satu identitas agama Islam diusik yakni ketika seorang non-Muslim (Ahok) dianggap telah menghina ayat al-Quran sehingga menyulut umat Islam yang dengan mudah terbakar emosinya dan mereka menuntut keadilannya dengan turun mengaliri jalanan bersama ribuan umat sesamanya yang diperintahkan oleh sebuah fatwa yang dikeluarkan MUI (Majelis Ulama Indonesia).

Kehadiran agama dalam realitas politik seperti yang terjadi pada Pilkada Jakarta ini, terdapat dua pandangan masyarakat tentang ada atau tidaknya isu-isu agama yang dijadikan alat politik bagi para kandidat. Sebagian kecil ada di antara mereka yang menilai bahwa isu-isu yang dijadikan para kandidat dalam kampanye politik

masayarakat kecil, terisolasi dan terbelakang. Tipe masyarakat ini menganut agama yang sama, karenanya keanggotaan mereka dalam masyarakat dan dalam kelompok keagamaan adalah sama. Bagi tipe ini agama tidak semata-mata sebagai suatu dukungan terhadap adat istiadat, tetapi sampai pada tingkat tertentu yang merupakan sistem tingkah laku atau tandingan terhadap sistem yang sudah disahkan. Tipe Kedua, masyarakat praindustri sedang berkembang yang memiliki karakter tidak terisolasi, berubah lebih cepat, daerahnya lebih luas cenderung tidak menggambarkan adanya penggunaan atas nama agama.

Alasan yang mereka gunakan karena kebanyakan masyarakat yang mempermasalahkan kasus penistaan al-Quran yang dilakukan Ahok sebagaimana yang sering dialamatkan oleh umat Islam sama sekali tidak ada kaitannya dengan agama, tetapi hal itu terjadi akibat ketidakmengertian masyarakat akan budaya dan seni itu sendiri, pernyataan semacam ini terutama banyak diungkapkan oleh masyarakat kalangan non-muslim, sekalipun di antara muslim itu sendiri ada yang berpendapat serupa.

Meskipun adanya pro kontra tentang penggunaan isu-isu agama dalam Pilkada, senyatanya isu-isu yang digunakan oleh para kandidat bersama tim suksesnya telah membawa implikasi tersendiri bagi masyarakat Jakarta. Masyarakat sering kali dihadapi dengan pertentangan sosial sebagai dampak dari perilaku politiknya baik dalam bentuk kekerasan fisik maupun psikis, maka tidak heran munculnya beragam konflik horisontal yang berlatarbelakang masalah Pilkada Jakarta.

Kedua, Secara garis besar kehadiran agama dalam aksi demonstrasi bernuansa agama tersebut akan selalu disertai dengan dua muka (Janus-face). Secara inhern, agama memiliki identitas yang eksklusif, partikularis dan primordial. Tetapi agama juga kaya akan identitas yang bersifat inklusif, universalis dan mengatasi (transcending). Sehingga penggunaan isu yang berlandaskan agama merupakan salah satu bukti untuk menjustifikasi bahwa agama dan politik tidak dapat dilepaskan, keduanya saling mengisi satu sama lain, meskipun di antara agama dan politik memiliki ciri yang dapat membedakan keduanya.

Penggunaan isu yang berlandaskan agama merupakan salah satu bukti untuk menjustifikasi bahwa agama dan politik tidak dapat dilepaskan, keduanya saling mengisi satu sama lain, meskipun di antara agama dan politik memiliki ciri yang dapat membedakan keduanya. Di antara isu-isu agama yang digunakan dalam Pilkada Jakarta tersebut bisa berupa penggunaan simbol

dengan populasi yang lebih banyak pula. Dalam tipe ini agama dipandang sebagai sesuatu yang tidak memberikan dukungan yang sempurna terhadap aktivitas sehari-hari. Tipe Ketiga, masyarakat industri dan sekuler. Ciri yang menonjol dalam masyarakat tipe ini adalah ditandai oleh kompleksitas organisasi keagamaan yang terpecah dan bersifat majemuk juga sudah terbiasa menggunkan metode empirik berdasarkan penalaran dan efisiensi dalam merespons permasalahan kemanusiaan. Tipe Keempat, percampuran antara tipe masyarakat di dunia modern. 
